\title{
Testing the inescapable network of mutuality: Albert Luthuli, Martin Luther King Jr and the challenges of post-liberation South Africa
}

\begin{tabular}{|c|c|}
\hline $\begin{array}{l}\text { Author: } \\
\text { Allan A. Boesa }\end{array}$ & $k^{1}$ (1) \\
\hline $\begin{array}{l}\text { Affiliation: } \\
{ }^{1} \text { Department } \\
\text { and Christian } \\
\text { of Theology, } ~ \\
\text { Pretoria, Pretc }\end{array}$ & $\begin{array}{l}\text { Ef Dogmatics } \\
\text { Ethics, Faculty } \\
\text { Iniversity of } \\
\text { ria, South Africa }\end{array}$ \\
\hline $\begin{array}{l}\text { Research Proj } \\
\text { Project Leade } \\
\text { Project Numb }\end{array}$ & $\begin{array}{l}\text { ct Registration: } \\
\text { r: J. Pillay } 10 \\
\text { er: } 04653484\end{array}$ \\
\hline $\begin{array}{l}\text { Description: } \\
\text { Prof. Boesak i } \\
\text { in the researc } \\
\text { 'African Christ } \\
\text { Development } \\
\text { by Prof. Dr Jer } \\
\text { Department o } \\
\text { History and Cl } \\
\text { Faculty of The } \\
\text { University of }\end{array}$ & $\begin{array}{l}\text { participating } \\
\text { project, titled, } \\
\text { ianity and } \\
\text { directed } \\
\text { ry Pillay, } \\
\text { f Church } \\
\text { urch Polity, } \\
\text { ology, } \\
\text { retoria. }\end{array}$ \\
\hline $\begin{array}{l}\text { Correspondin } \\
\text { Allan Boesak, } \\
\text { bonhoeffer1@ }\end{array}$ & $\begin{array}{l}\text { g author: } \\
\text { gmail.com }\end{array}$ \\
\hline $\begin{array}{l}\text { Dates: } \\
\text { Received: } 24 \\
\text { Accepted: } 17 \\
\text { Published: } 25\end{array}$ & $\begin{array}{l}\text { Jct. } 2018 \\
\text { Feb. } 2019 \\
\text { July } 2019\end{array}$ \\
\hline $\begin{array}{l}\text { How to cite th } \\
\text { Boesak, A.A., } \\
\text { the inescapab } \\
\text { mutuality: Alb } \\
\text { Martin Luther } \\
\text { challenges of } \\
\text { South Africa', } \\
\text { Studies/Theol } \\
75(4), \text { a5297. } \\
\text { 10.4102/hts.v }\end{array}$ & $\begin{array}{l}\text { is article: } \\
\text { 2019, 'Testing } \\
\text { le network of } \\
\text { ert Luthuli, } \\
\text { King Jr and the } \\
\text { post-liberation } \\
\text { HTS Teologiese } \\
\text { ogical Studies } \\
\text { ittps://doi.org/ } \\
75 i 4.5297\end{array}$ \\
\hline $\begin{array}{l}\text { Copyright: } \\
\text { (c) 2019. The } \\
\text { Licensee: AOS } \\
\text { is licensed un } \\
\text { Creative Com! } \\
\text { Attribution Lic }\end{array}$ & $\begin{array}{l}\text { uthors. } \\
\text { IS. This work } \\
\text { der the } \\
\text { nons } \\
\text { ense. }\end{array}$ \\
\hline Read online: & \\
\hline 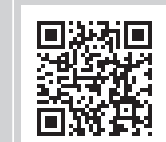 & $\begin{array}{l}\text { Scan this QR } \\
\text { code with your } \\
\text { smart phone or } \\
\text { mobile device } \\
\text { to read online. }\end{array}$ \\
\hline
\end{tabular}

The assassination of Martin Luther King Jr, 50 years ago on 04 April 1968, has been recalled in the United States with memorial services, conferences, public discussions and books. In contrast, the commemoration in 2017 of the death of Albert John Mvumbi Luthuli, 50 years ago on December 1967, passed almost unremarked. That is to our detriment. Yet, these two Christian fighters for freedom, in different contexts, did not only have much in common, but they also left remarkably similar and equally inspiring legacies for South Africa, the United States and the world in the ways they lived their lives in complete faith commitment to ideals and ways of struggle that may guide us in the ongoing struggles to make the world a more just, peacable and humane place. For South African reflections on our ethical stance in the fierce, continuing struggles for justice, dignity and the authenticity of our democracy, I propose that these two leaders should be considered in tandem. We should learn from both. This article engages Martin Luther King Jr's belief in the 'inescapable network of mutuality', applies it to the struggle for freedom in South Africa and explores the ways in which South Africans can embrace these ethical ideals in facing the challenges of post-liberation.

Keywords: Black consciousness; Black struggle; Black churches; South Africa; United States; Albert Luthuli; Martin Luther King Jr.

\section{A tent and a voice at midnight}

The year was 1968, the year of my ordination as a 22-year-old in Immanuel Dutch Reformed Mission Church congregation in Paarl, South Africa, a town at the foot of the mountains nestled in the breathtakingly beautiful Winelands country of the Western Cape. My congregation was in turmoil, in the throes of forced removals as a result of apartheid laws: as it would everywhere, the Group Areas Act, the refinement of the 1913 and 1936 Land Acts had come to Paarl. It struck with its familiar, relentless cruelty. Most of the town had been declared a 'white' area. All those classified 'non-white' were forcibly removed to east of the river, had their homes confiscated or bulldozed, their sacred buildings desecrated: sold insultingly cheap - communities under this sword of Damocles had no power, nor the strength to negotiate with the inevitable - to be used for something more useful to white people, or razed to the ground. Families who had lived there for generations would hold out as long as they could. Finally, however, they would be moved, their communities and memories, their history and their dreams violently uprooted, sometimes eventually obliterated. All of a sudden the beauty of this place - a 'pearl' glittering in the Boland sunrise - would be forever scarred by the ugliness of apartheid from which there would be no escape anywhere. It was a time of great upheaval, turmoil and anger; a time in great need of the word of prophetic truth. I, however, was completely unprepared for the challenges of justice to my ministry. ${ }^{1}$

It was the year of the discovery of the total inadequacy of my theological training at my seminary where I was tutored by teachers from the white Dutch Reformed Church who believed in the theology of apartheid, white supremacy and the divine right of the Afrikaner, as God's chosen people, to lay claim to the land of my ancestors, the determination of my future, the content of my dignity and the definition of my freedom. It was the year of my final farewell to that bland but toxic mixture of Reformed theology, European pietism and Afrikaner Volksromantik, that utterly distorted version of the radical Calvinist tradition, what Martin Luther King Jr called 'a completely

1.There is yet another side to this story, a powerful encounter with an older woman in the church, her exposure of my inadequacies and her challenge to and encouragement in my ministry (see Boesak 2009:33-34). 
other-worldly religion which makes a strange, un-Biblical distinction between body and soul, between the sacred and the secular'2 (King 2015b:142). This would be the year I discovered that my discontent with the world and the church (as it was then) could not grow any worse. King's powerful, rhythmic litany of 'divine dissatisfaction' with American apartheid would become mine with South African apartheid (King 2015d:178-179).

It is not as if I had not seen and experienced the devastating workings of the Group Areas Act before. The destruction of Cape Town's famed District Six and Johannesburg's Sophiatown and their communities was already becoming the stuff of legend. Somerset West, my hometown a scant hour away, was hit by those same laws and my family was one of thousands who had lost our home. So the anger, the sense of injustice and the frustration of not being able to do anything meaningful about it were not new. But I was not asked to stand in the pulpit preach about this particular evil in Somerset West, expected to offer both succour, comfort and the promise of justice from the Word of God to my people as I was in Paarl. In Somerset West I was a young person, angry at what was happening to my family, not yet fully seeing the wider implications of these events and not yet reading the signs of the times the way I would later. In Paarl I was a pastor who was called upon to speak to the angry and fear-filled hearts of my church, on behalf of all our people struck by this injustice, and in the name of the God of justice. This is just one of the many reasons why I have such complete understanding for the preachers of the Gospel and imams and pastors in occupied Palestine as they seek to serve their people engaged in the life and death struggles against the Israeli occupation, their brutalities of land-theft and war.

It was also the year of the publication of the South African Council of Churches' Message to the People of South Africa, the attempt by mainly white theologians to articulate the sinfulness of apartheid, following on the 1960 Cottesloe Declaration. $^{3}$ But it was simultaneously the dawning of my understanding that in a situation of struggle, pain and suffering, commitment means, to quote Rev. Beyers Naudé, 'the time for pious words is over' (Naudé 1963:9). ${ }^{4}$ My pious

2.In truth, this process had already begun in earnest with my introduction to Rev Beyers Naudé in 1965, and his careful explanation of the pivotal importance of the need for moral, biblical and theological justification of apartheid in the ideology and need for moral, biblical and theological justification of apartheid in the ideology and practice of that system especially for those in the Afrikaner community for whom it was so vitally important to have 'God on their side'. But the difference in preaching and activism was considerable.

3.For a more detailed discussion of the Cottesloe Declaration from a black point of view, see Allan Aubrey Boesak (2015:76-82). The Message was a brave theological see Allan Aubrey Boesak (2015:76-82). The Message was a brave theological
document identifying apartheid as a 'novel gospel' and calling upon Christians to document identifying apartheid as a 'novel gospel' and calling upon Christians to
choose the way of obedience to God rather than human beings, but lacked completely the urgency of involvement in the struggle, of having taken sides in the struggle, even of an awareness that a struggle was going on, of black Christians' wrestling to connect their faith to that struggle, or that the choice for 'obedience to God' actually mean commitment to and participation in that struggle as the critical dimensions of one's faith such as Albert Luthuli showed by example throughout his life.

4.These words are from a key sentence in a crucially important article in which Naude defends his decision to openly support the World Council of Churches' Program to Combat Racism and its Special Fund that provided financial support to Souther African liberation mover African liberation movements. The article, significantly titled 'The Parting of the Ways' (Pro Veritate, October, 1970), signals the intensifying of the tensions betwee Naude and the white population of South Africa, Afrikaans and English-speaking alike, as Naude's solidarity with the freedom struggle signified more and more personal commitment and involvement (see Boesak 2015, chapter 3, especially $75-82$ words from the pulpit would not be enough, would not assuage the hunger and thirst for justice in those sitting in the pews, and would not suffice in the struggle against a system declared a crime against humanity, a sin, a heresy and a blasphemy.

In April of that year Martin Luther King Jr was murdered, and while the stunned grief that reverberated around the world echoed in black South Africa, in the pages of an Afrikaans Sunday paper they reported it with undisguised glee. I did not know him of course, but I knew of him. Clearly though, the apartheid regime did know him, and greatly feared him and his influence, especially over young, black South Africans in danger of discovering the power of faith in the revolutionary Gospel of Jesus of Nazareth. Nothing could be read of or about King. His books, recordings of his sermons and speeches, everything he had said, were banned by the government: forbidden. Reading banned material was an offence against one or other of the vast array of draconian laws enacted by the apartheid regime. In this time, Rev. Dale White of the well-known Wilgespruit Conference Centre in Johannesburg, a preacher, activist and mentor to many from the Johannesburg townships, went on trial because, among other deeds considered seditious by the apartheid regime, he had disseminated a recording of a Martin Luther King speech.

In September of that year, I was leading the Bible study at the week-long spring camp for the Association of Christian Students. Among those forced to attend were some 300 young people from high schools across the country, the few teacher colleges and the one university person classified as 'mixed race'. At some point during that week, someone whispered in my ear and asked whether I wanted to listen to 'a secret tape'. It was a tape recording of Martin Luther King's sermon at the National Cathedral in Washington, DC, earlier that year, 'Remaining Awake Through a Great Revolution' (Washington 1986:268-278), ${ }^{5}$ beginning with King's masterful retelling and application of the Rip van Winkle story. It was perhaps the same recording Rev. White was on trial for.

This article, firstly, discusses the impact of that concept on the generation that was to lead the struggle in its final phase against apartheid. It seeks to explore the meaning of those words for Martin Luther King Jr, his work and his life, and their impact on his growing understanding of its truth concerning worldwide struggles for freedom and justice. It seeks, secondly, to understand their meaning in the interconnectedness with Albert Luthuli, his Christian leadership in the struggle against apartheid in South Africa. And thirdly, it will ask to what extent this concept has lessons to offer South Africans as we struggle to find the right ways towards genuine democracy in post-liberation South Africa, and in our relations with global struggles for justice.

5.This was a recording of the sermon Dr King preached at the National Cathedral in Washington, DC, which was to be his last full Sunday sermon before his death 4 days later, see https://kinginstitute.stanford.edu/king. For the text of the sermon, see later, see $h$ ttps://kinginstitute.stanford.edu/king. For the text of the sermon, see
Washington (1986:268-278). King makes references to this story in several speeches and sermons before this final delivery (see, e.g., King 1967:170-171). 
Listening to that smuggled-in tape that night, I was struck with awe, not just by that voice, by the gripping, soaring rhetoric, or by what I would come to know as the rhythmic, mesmerising cadences of black Baptist preaching from America. I was moved by the prophetic unfolding of the story for us at that time - by the sheer power of the truth he spoke so plainly and fearlessly. I did not know him, did not understand American politics or the struggle for racial justice there - certainly not in the way I was beginning to understand more and more the dynamics of our own struggle - did not even know where precisely Washington, DC, was. Why then was I so moved, so stirred with anger, so compelled by the power of his words? Why was I so convinced that we, black South Africans and the black church in South Africa, were the ones sleeping through the great revolutions of our time, including our own? Why did I feel that I understood intuitively what black Americans were enduring, hoping and fighting for; that our struggles were intertwined, that the justice Martin King was talking about as the desire of God and his people was also the justice our people called for, in my church and right through South Africa? Why did I immediately understand that our thinking was too small, unworthy both of our situation, our calling, and our God; that we were so intent on the 'windows of opportunity' opened ever so slightly at the whim of the powerful and privileged that we did not even see the doors opened wide by the God of history?

It was not because of the rudimentary connections between the anti-apartheid struggle and the civil rights struggle that certainly did exist at the time but that we were mostly unaware of. I did not then know that in 1962 Martin Luther King Jr and Albert Luthuli had both signed the appeal to Western governments to isolate the apartheid regime through sanctions and divestment. And in this relationship there was a radicalisation in King that paralleled his radicalisation vis-à-vis the American situation. However, in 1958 King referred to the apartheid regime as a 'government who sponsors a more rigid program of segregation' (see Baldwin 2006:57); that polite language was gone by $1965 .{ }^{6}$ Nor did I know of Martin King's real admiration for our own Defiance Campaign of the 1950s and Luthuli's fearless leadership, inspired by his Christian faith. Lewis V. Baldwin, that great King scholar who has written more extensively than anyone on the relationship between Martin King and South Africa, informs us that King had addressed the problems of the oppressed in South Africa from the time he assumed the pastorate of the Dexter Avenue Baptists Church in Montgomery, Alabama, in the mid-1950s (Baldwin 2006:54; see also Baldwin 1995). Baldwin also discloses the growing relationship of comradeship between Albert Luthuli and Martin King even though the two men never met.

6.King's awareness of the interconnectivity and interdependence of our struggles would grow as his commitment to both would deepen. See Martin Luther King Jr 'Let My People Go' a speech given on 10 December 1965 in support of the anti'Let My People Go', a speech given on 10 December 1965 in support of the antiapartheid struggle (King 2015d:107-112). His powerful opening sentences set the tone for the judgement on apartheid, its leaders and beneficiaries, and the call fo non-violent, militant resistance on an international scale: 'Africa does have spectacular savages and brutes today, but they are not black. They are the sophisticated white rulers of South Africa who profess to be cultured, religious and civilised, but whose conduct and philosophy stamp them unmistakably as modern day barbarians' (p. 107)
Their convictions, commitments and leadership acted as mutual inspiration (Baldwin 2006:58). ${ }^{7}$

King understood the interconnectivity, but he was not naive he knew that South Africans were involved 'in the far more deadly struggle for freedom' (Baldwin, in Smith 66; also Baldwin 1995:45-46). It was because what Martin King said rang undeniably true: 'We are caught in an inescapable network of mutuality, tied in a single garment of destiny. Whatever affects one directly, affects all indirectly'. And then, in words that years later I would recognise as echoes of Ubuntu, making the universal intensely personal and the personal intensely political, 'for some strange reason I can never be what I ought to be until you are what you ought to be. And you can never be what you ought to be until I am what I ought to be' (King 1986:269). ${ }^{8}$ It was the first time I had heard that expression. Suddenly my world was wider than apartheid-confined South Africa, the struggle became broader, deeper, more inclusive, more demanding, encompassing much, much more than the struggle against apartheid. It became international and multi-faceted. Many years later we would speak of 'global apartheid'..

Later I would understand why there was such a strong spiritual kinship between Martin Luther King Jr and Albert John Mvumbi Luthuli, the most remarkable Christian leader of the African National Congress in the 1950s, as I would come to understand the spiritual kinship between the civil rights struggle and the anti-apartheid struggle. I would also come to understand why, in his acceptance speech for the Nobel Peace Prize in 1964, Albert Luthuli would be the only person Martin King would quote by name (see King 1986:224-226). Their radical, combatant love for their people was grounded in their complete love for Jesus Christ. He was preaching in Washington, DC, but he was talking about, and to, all of us. On that day I, and as I would discover later, a large section of my generation, embraced Martin Luther King $\mathrm{Jr}$, and even in this we were not the first, as we have already seen. From the moment Walter Sisulu appealed to King for solidarity (Baldwin, op. cit., in Smith 2006:55) and King's growing involvement with South Africa through the American Committee on Africa, this embrace was a reality. ${ }^{10}$ But for my generation it was an initial embrace. Martin, we ourselves, and that embrace would become much more complex, even as for me, it became more compelling

\footnotetext{
7. In response to a report from King's friend, G. Mcleod Bryan, who visited Luthuli, then under a banning order in South Africa, conveying to King Luthuli's admiration for his work and appreciation for his book Stride Toward Freedom, King wrote back to Luthuli: May I say that I, too, admired you tremendously from a distance. ... But to Luthuli: May I say that I, too, admired you tremendously from a distance. ... But
I admire your great dedication to the cause of freedom and dignity. You have stood
amid persecution, abuse, and oppression with a dignity and calmness of spirit amid persecution, abuse, and oppression with a dignity and calmness of spirit
seldom paralleled in human history. One day all of Africa will be proud of your achievement (Baldwin in Smith 2006:58).

8.This is also argued to great effect in his 'Letter from a Birmingham Jail', but King would make this point persuasively in a variety of contexts. Clearly, it is a truth he held dearly and wanted to imprint upon his audiences and followers at every opportunity.

9.According to South African economics scholar, Patrick Bond, this very appropriate term was first introduced by former president Thabo Mbeki at the World Summit for Sustainable Development, Johannesburg, 2002, see Patrick Bond (2004:817-839).

10.For King's role within the US Anti-Apartheid Coalition, see Baldwin, op. cit., in Smith 2006:54-69.
} 
(see Baldwin 2006:70-78). That embrace would deepen to more critical dimensions, and as Martin Luther King became more radicalised, our embrace would become the embrace of the radical King (see West 2015a). This process of radicalisation would show how serious Martin King was when he reminded his audience at the National Cathedral of the poet John Donne's famous words: 'Any man's death diminishes me because I am involved in mankind. [sic] Therefore never send to know for whom the bell tolls, it tolls for thee'. Then he went to say, 'We must see this, believe this, and live by it ... if we are to remain awake through a great revolution' (King 1986:270). Martin King (1986) said one other thing that stirred me deeply, and which would become a guiding light for my activism in years to come:

Somewhere we must come to see that human progress never rolls in on the wheels of inevitability. It comes through the tireless efforts and the persistent work of dedicated individuals who are willing to be co-workers with God. (p. 270)

At this 50th commemoration of his assassination, we inquire to what extent some of the fundamental truths Martin Luther King Jr has tried to teach coming generations are still relevant and what we can learn from those in our current, continuing struggles.

\section{A decade of tumult}

For South Africans, the 1960s was a decade of great tumult and deep disorientation. In Cape Town, but especially at Sharpeville, the people's courage was sledgehammered into the ground by apartheid's brutal power. The government banned the liberation movements, its leaders and its activists. Black political activity, such as survived, was driven into exile or underground. Leaders were imprisoned. Robben Island, long a symbol of banishment and resistance, became iconic. The vibrancy of Christian activism that had become a hallmark of the Defiance Campaign had been virtually abandoned. The prophetic church had lost its voice. Our world was shaken. What was left was Luthuli's yearning for its return:

It is my hope that what began, in the way of Christian involvement and thinking out, at the time of the Defiance Campaign, will not simply drain away, leaving Christians in despondency and impotence, adapting themselves fearfully to each new outrage, threat, and assault upon the people in our care. There is a witness to be borne, and God will not fail those who bear it fearlessly. (Luthuli [1960] 2006:132)

The young generation who towards the end of the decade and at the beginning of the 1970s embraced Black Consciousness and Black Theology, who rediscovered their power in the challenges of Black Power, and the young activists who in 1976 and from 1983 onwards took their faith, anger and hope into the streets of protest and the manifold ways of militant, non-violent resistance had heard him. And they did so with a depth of courage that will continue to amaze and shape history because like Luthuli, they knew, and experienced, that 'God will not fail those who bear it fearlessly'.
In 1948, apartheid became the official policy of South Africa. Unvarnished white supremacy was turned into the law of the land. But there were three remarkable things about apartheid that uniquely shaped our struggle.

Firstly, apartheid, even though a drastic modification of the segregation policies brought by colonialism, and a consequential historical development of slavery, was a direct result of the continued intervention and unceasing hard work of the white Dutch Reformed Church. In fact, as Rev. D.P. Botha argued persuasively some time ago, it was a political policy in many ways derived from and based on the mission policy of that church, in place since 1857 (Botha 1980:68-69). Hence, it was with complete justification that the official organ of the Dutch Reformed Church Die Kerkbode (1948), wrote in jubilation that the victory of the National Party at the polls that year was not just God's divine will, but asserted proudly that apartheid was 'a church policy' (Van der Westhuyzen 1948:664-665). Secondly, which was quite unique, also put in place was an elaborate, systematic theological construct, called the theology of apartheid, the biblical and moral justification of the policy, absolutely essential to the upholding of the policy and to the construction of the myth of white chosen-ness, white innocence and white divine right (see, e.g., Lombard 1981; Kinghorn 1986).

Thirdly, after 1948 the resistance from the majority of the population moved from what Nelson Mandela would later call 'constitutional protest' to open defiance. That gave rise to the non-violent campaigns of the 1950s known as the Defiance Campaign, and sporadically into the first months of 1960, challenging the unjust apartheid laws and practices with mass actions of civil disobedience until the brutal crackdowns of the regime forced an end to it all, at least for that time period. After the Defiance Campaign, other acts of non-violent resistance such as the 'Potato Boycott' of 1959 (Luthuli [1960] 2006:215-217) as well as the subsequent campaigns against the municipal beerhall system, the dipping tanks and especially the hated 'Pass Laws' (Luthuli [1960] 2006:215-217) had no institutional church support, ${ }^{11}$ but Christians participated in their thousands nonetheless, considering themselves part of a people's movement led by strong Christian leadership like Albert Luthuli and Robert Sobukwe. What we saw was the emergence of the prophetic church, what Martin Luther King called the 'inner, spiritual church, the church within the church, the true ekklesia and hope of the world' (King 2015b:142) and what South African pastor/activist Frank Chikane would refer to as 'the church of the streets'. ${ }^{12}$ the churches regarding the Defiance Campaign and thescatating repression from the apartheid regime, wrote: What did the churches do about this? Except for the lone stand made by Bishop Reeves, who refused to hire church buildings out for the Verwoerd secular education for serfdom, almost nothing (Luthuli [1960] 2006:131).

His critique is scathing. He speaks of 'the wreck of [prophetic] Christian witness', and what he fears was a 'slow drift into a Nationalist state religion' (p. 132).

12.In contrast, because the black church in the United States was an institution owned and run by African Americans, and had such a strong history of prophetic leadership in the struggle against slavery and racial oppression in the United States, the civil rights movement had considerable support among laypersons as well as civi rights movement had considerable support among laypersons as well as clergy, even though it has to be said that even there it was not the black church as a whole that supported the struggle. The degree of resistance to Martin King's leadership the Southern Christian Leadership Conference and the struggle, in general, from many church leaders, their churches or representative bodies was astonishing and shameful. Nonetheless, it is fair to say that without the prophetic black church in the United States there would have been no Martin Luther King Jr, and no civil rights struggle (see, e.g., Baldwin, 2006:59). 
As a result, and authenticating the truth preached more than a century ago already by Frederick Douglass (1857), ${ }^{13}$ followed by Albert Luthuli ([1960] 2006:124], ${ }^{14}$ and Martin Luther King (2015b:131) ${ }^{15}$ that the oppressor never surrenders power without a struggle, the 1960s also brought us the Sharpeville massacre, the consequent suppression of all black political activity, the banning and exile of black political leadership, the banning of the liberation movements, the Rivonia trial, following the Treason Trial of the 1950s, and the imprisonment of hundreds of activists and leaders, among them Nelson Mandela. In the aftermath of Sharpeville, in December 1961, the African National Congress took the decision to embark on military struggle, a decision which would cause deep divisions within the movement as well as between its most prominent leaders, Albert Luthuli and Nelson Mandela (Couper 2010:152-184; 235ff; also Boesak 2015:182-192). That decade also saw Mandela's capture, the Rivonia Trial and his imprisonment with many others. We would not see him for the next 27 years. Albert Luthuli died in $1967 .{ }^{16}$ Sharpeville was a defining moment for the apartheid regime, as it was a defining moment for the struggle. ${ }^{17}$ It also became a defining moment for the churches.

Although the white Dutch Reformed churches were in full support of apartheid, the white, moderate leadership of the multi-racial English-speaking churches responded with resolutions and statements, all the while seeking to calm the waters, calling for caution and warning against 'extremism' and violence 'from both sides'. In this too, we understood Martin Luther King Jr: we too saw a church:

more devoted to 'order' than to justice; who prefers a negative peace which is the absence of tension to a positive peace which is the presence of justice... [white church leaders who] paternalistically believe they can set the agenda for another man's freedom ... (King 2015b:135)

What King says about 'moderate' white church leaders here is ipso facto true for liberal white South Africans, clerical and secular both, who found it hard to resist the temptation to set the agenda for black freedom. ${ }^{18}$

Chief Albert Luthuli's response to mining magnate Harry Oppenheimer, unsurprisingly similar to his response to

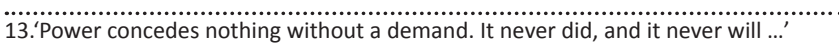

14.'Our struggle is a struggle and not a game - we cannot allow ourselves to be daunted by a harshness which will grow before it subsides. We shall not win our reedom except at the cost of great suffering, and we must be prepared to accep the spilt, and assuredly more will be ... We do about the price he will exact in African blood before we are admitted to citizenship in our own land.'

15.'Lamentably, it is an historical fact that privileged groups never give up thei privileges voluntarily. ... We know through painful experience that freedomis never voluntarily given by the oppressor. It must be demanded by the oppressed'.

16.To this day the unease surrounding his death, whether he really 'got lost', wandered towards the railway lines and was killed accidentally by a train, refuses to come to rest.

17.In the same way, I argued elsewhere, the Marikana massacre of 2014 has become a redefining moment for the ANC, it will continue to have far-reaching consequences for the ANC as a political movement and its political and moral leadership in politics in South Africa (see Boesak 2014:6-10).

18.The language and argumentation in the section on 'Church Theology', and the subsections 'reconciliation', and 'violence' in the South African Kairos Document would reflect these viewpoints quite powerfully. white liberal church leaders, is a case in point. 'After a preliminary declaration of his understanding of the African point of view', Luthuli recalls, Oppenheimer 'took us to task over what he sees as the excessive nature of our demands and methods, 'such things as the demands for votes and the methods of public demonstration and boycott'. The 'extremism' of the oppressed masses 'made it difficult for him and others like him to persuade "liberal-minded people" of his own group of the justice of those demands' (2006:166). Luthuli (2006) relates that what was important for $\mathrm{Mr}$ Oppenheimer to understand, was that

however 'unpleasant' our demands might seem, they are real demands, and that it was far better that white South Africa should here and now know their nature than be constantly taken by surprise by being admitted to our thoughts instalment by instalment. (pp. 66-167)

Towards the end of the decade, Black Consciousness would embrace this same political suspicion and revolutionary impatience with 'the white liberal' who simply could not conceive of black people's agency in shaping the agenda and pace of their own struggle for freedom, who were always afraid of black 'excessiveness' in our demands and disapproving of black people's desire to define their own freedom. White liberals are so engrossed in their prejudices, writes Biko (1975:59-62), that they cannot believe that black people can formulate their own thoughts without white curatorship. ${ }^{19}$

What we desperately needed in fact was not the cautionary cowardice of white paternalism, nor the endless patience, resignation and pseudo-innocent complicity of black conformism, but the 'maladjustment' (King's term), of the 8th-century prophets of the Hebrew Bible in their unremitting challenge to the powers of oppression and injustice and their prophetic faithfulness and the extremism of Jesus in his outrage at injustice in his love for justice. So the question always is, King argued, not whether we should be extremists, but rather what kind of extremists we should be (King 2015b:138). What we needed was a church who understood the radical demands of the Gospel, the interrelatedness of life and the indivisibility of justice. A church that understood that there was a revolution going on in the world - in Africa, Asia, Latin America, the United States and South Africa. But the decade of the 1960s also saw the silencing of the prophetic church in South Africa. And, like Luthuli, we should be 'quite extreme on this point', and like Luthuli, not be afraid to say it (Luthuli [1960] 2006:132).

When Martin King called for the United States, and for all people of good will to 'get on the right side of that revolution' because 'the great masses of people are determined to end the exploitation of their races and their lands ... They are awake and moving toward their goal like a tidal wave ...' (King 1967b:170), he was also talking about us as well as to us. Those 'shirtless and bare-footed masses' of the world were $u$ s. Referring to this 'tidal wave' of revolutionary change

19.In this way even whites, who admit the many faults in the system, are keen to correct the response of Blacks to the provocations [of that system]' (p. 60). 
as the 'continuing story' for freedom from the time of the exodus, he said, 'Something within has reminded the Negro of his birthright of freedom, and something without has reminded him that it can be gained' (King 1967b:170)

But if African Americans should see God at work in history, and be reminded of their birthright by the struggles for freedom and justice in Africa, Asia and Latin America, should we, conversely, also not see God at work in the civil rights struggle in the United States, and should not we be reminded of our birthright because of their struggle? Is 'the network of mutuality' not also networks of unbreakable solidarity and revolutionary reciprocity? And is the 'single garment of destiny' not our common destiny of peace, freedom and human dignity? And is the human dignity we seek not also for the whole human community, including our oppressors, not just for ourselves alone? (see Boesak 2017:147-168). The answer, it seems to me, is a clear 'yes'. The interconnectedness, the network of mutuality, is also more than politics. It is fundamental to our common humanity, to our obligation to restore to the world a human face.

But here is something remarkable. Although the prophetic church in South Africa was driven underground, silenced by suppression, the banning, imprisonment, fear and the killing of its prophets - a time in which the 'Word of God was scarce' (1 Sam 3), a time of crisis and testing for prophetic faithfulness - God allowed a new generation to hear the Word from another part of the world. The prophetic church in the United States was not silenced, had in fact begun to gain a new strength and a new urgency, driven by new insights into the crises of their own society and our world. At a time when Martin Luther King Jr was maturing into greater, deeper, more radical wisdom, seeing with clearer eyes the indivisibility of God's justice, the oneness of God's world, the inescapable network of mutuality and the single garment of destiny, this is the time this message - a secretly smuggled tape recording - comes to awaken the prophetic church in South Africa, reminding us of the way in which the prophetic church in South Africa had inspired the black people struggle for freedom in America. This is no coincidence, but the way the Spirit of God works to keep God's work of liberation and hope alive in the world.

\section{Understanding the solidarity of struggle}

The most remarkable thing about Rip van Winkle, Martin King pointed out, was not that he slept for 20 years, but that he slept through a revolution. That was certainly true of the church of my generation, and of us, the children of that generation. It took Martin King's words to help wake us up. We embraced Martin Luther King because he awakened us to the fact that we too have been in a struggle, but like Rip van Winkle, my generation has been asleep while momentous events were occurring in Africa and around the world. We were asleep in another aspect as well. In our many urgent discussions, debates and engagements with each other about the unfolding struggle and our role in it, we discovered that those of us calling ourselves Christian activists have mostly been dealing with effects, rather than with causes. We were dealing mostly with the effects of racism, the effects of poverty, the effects of disenfranchisement. It was time to wake up, understand and engage the causes.

So towards the end of the 1960s and the beginning of the 1970s, with the coming of the Black Consciousness movement and the courageous and impeccable leadership of Stephen Bantu Biko, we began to think about the deepest roots of white supremacy and racism; the causes of powerless and the meaning, use and abuse of power; the systems of economic exploitation and the systems of domination rampant in the world. We began to think how these systems work nationally and globally, our subjection to them, our compliance with them and our complicity in them. We began to understand better how white racism, as a particular South African phenomenon, was entrenched in white supremacy and white privilege globally and how these functioned as manifestations of white power, hand in hand with social engineering, economic exploitation and political oppression.

In 1963, in the Letter from a Birmingham Jail, Martin Luther King Jr uses the phrase 'the white power structure' only once, almost as a casual afterthought, and confined to the city of Birmingham. Later, towards the end, he would use that phrase much more thoughtfully, much more systemically, much more globally. We came to understand that phrase, its reality and its consequences for South Africa and for the world we live in. It also indicated a radicalisation in King's thinking that would grow in maturity and effectiveness in his ongoing engagement with power structures in the United States, and as the United States exerted its power across the world, though he would not come to recognise it explicitly as the power exerted by empire.

We took Martin King seriously too, when he spoke of his distinction between constitutional rights and what he called 'God-given' rights. We understood him to mean that he understood that while the United States had a constitution, that same constitution saw black people as 3/5ths of a human being, therefore not guaranteeing the human rights, the Godgiven rights, of black people. In that constitution equality was mentioned, but selectively applied; freedom was a word but not a reality; dignity was not even mentioned. So it was necessary to appeal to something that came from 'beyond the dim mist of eternity', that no document from human hands could deny, redefine, change or diminish. Yet, time after time, Martin King would appeal to that constitution, in an effort to find common ground with what white America would consider the proud foundation of their democracy, for them the 'greatest in the world'. ${ }^{20}$

In South Africa, in contrast, we had no constitutional democracy. The constitution was a racist, apartheid constitution. There

20.It was an inherently contradictory appeal however, and not sustainable but Kin clung to it because like Frederick Douglass before him, he believed that the Constitution guaranteed the freedom of all Americans, not just white people. The Constitution did not sanctify racism, they believed, but rather revealed the utter hypocrisy of white Americans, and calling them on it was the moral responsibility of black people. Malcolm X, of course, held the opposite view (see Cone 1991: Introduction). 
could not even be the pretence of appealing to the constitution, but following Martin, we appealed to our God-given rights. Not just the right to freedom, but the right to freedom that guaranteed and protected dignity; not just the right to vote but the right to have a voice; not the right to pursue individual happiness but the right to secure the common good in the name of our shared humanity. We fought for the right not to go hungry; not to be exploited, not to be exiled at will; the right to shelter, the right to have choices, the right to hope and work for a better, more humane, more just world. It is this understanding, fashioned in the vortex of struggle, burnished in the flames of hope and moulded on the anvil of sacrifice that informed the values of South Africa's struggle and its current Constitution, one of the most progressive documents in the world with the exception of our flawed private property clause. ${ }^{21}$

In the deepening dimensions of our struggle, we came to realise that for Martin 'the network of mutuality' was not just a geographical inescapability, but an embraced, qualitative inclusivity. Hence, it was quite natural for us, in the writing of the Belhar Confession, 22 to insist upon God as first and foremost the God of compassionate justice the One who wants to bring about justice and true peace on earth'. For that reason, Belhar urges the church 'to stand where God stands', to 'witness and strive against any form of injustice', so that for everyone who is despised, rejected, wronged, destitute, excluded or discriminated against 'justice may roll down like waters, and righteousness like a mighty stream'. Hence also the firmness of the rejection, as it is in the affirmation: 'Therefore, we reject any ideology which legitimates any form of injustice'. The 'inescapable network of mutuality' that included black people as well as white people, African Americans as well as oppressed people across the world, poor white people, poor black people, poor Latinos from all parts of America, as he was recruiting for the 'Poor People's March', would have had to include women and LGBTQI+ persons, who were also an inextricable part of the 'single garment of destiny'. Following Martin King's (radicalising) logic, such a conclusion is entirely plausible. ${ }^{23}$ Because without them our humanity would never be complete. We would, as he himself understood full well, never be what we ought to be, unless they are what they ought to be. It was, for me, an extraordinarily liberatory understanding (Boesak 2015:112-117).

\section{The road to freedom}

We listened and agreed because we knew it to be true, when Martin King told us that 'freedom is never voluntarily given by the oppressor; it must be demanded by the oppressed'. From our own history we understood that freedom is always

21.As I write, the debates on the amendment to the Constitution to change this clause to allow land restitution without economic compensation are raging across the
country. It may have been unnecessarily postponed for 25 years, but it is not too late and absolutely imperative to make our reconciliation process credible, durable and sustainable.

22.The full text of the Belhar Confession is available at https://www.pcusa.org/site media/media/uploads/theologyandworship/pdfs/belhar/pdf.

23.See the convincing case made by Traci $C$. West on this issue, 'Gay Rights and the Misuse of Martin' (Baldwin \& Burrows 2013:141-156). the fruit of struggle and pain and sacrifice. We recognised it because King echoed the words of our own Albert Luthuli who taught us that 'the road to freedom is via the CROSS' (Luthuli [1960] 2006:232-236) and Nelson Mandela, like Luthuli before him, testified that the ideals of the struggle are ideals we should live for, and if necessary, be ready to die for. ${ }^{24}$ Frederick Douglass, over 160 years ago, saw it well:

If there is no struggle, there is no progress. Those who profess to favor freedom and yet deprecate agitation are men who want crops without plowing up the ground; they want rain without thunder and lightning. They want the ocean without the awful roar of its many waters. The struggle may be a moral one, or it may be a physical one, and it may be both moral and physical, but it must be a struggle. Power concedes nothing without a demand. It never did and it never will. ... The limits of tyrants are prescribed by the endurance of those whom they oppress. ${ }^{25}$

So when our time came and we recognised God's kairos for our generation, we asked God to forgive our complicity and our cowardice and we embraced the radical demands of the Gospel, for ourselves and for our struggle. But because Martin King convinced us that struggle without love is freedom held captive, we tried, under the most difficult circumstances, to remember that liberating the oppressor is our historic obligation, and that the ubuntufication of the world is integral to the call for justice. ${ }^{26}$

It is for that reason that in the final analysis black South Africans, in our choice for reconciliation and reconciled diversity, chose political justice rather than victim's justice; distributive justice rather than retributive justice; justice for the living rather than revenge for the dead; a reconciled future rather than an unforgiven past; a shared hopefulness rather than a negotiated despair. ${ }^{27}$

When Martin spoke of the power of non-violence he reminded us of our own struggle, and how we, under pressure of the violence and intransigence of the oppressor, chose the road to violence, in the process becoming more like the oppressor than we had wanted to be or could foresee that we would. We remembered then that Luthuli told us that we should not succumb to the oppressor's invitation to desperation, and that he warned us not to give up the militant, non-violent struggle. And so, returning to and leaning upon the wisdom of Albert Luthuli, it was possible for a new generation, after the quiet despair of the 1960s, even while understanding the choices Nelson Mandela and

24.See Nelson Mandela's speech from the Dock, 'I am Prepared to Die', http://www. historyplace.com/speeches/mandela.htm.

25.See Frederick Douglass, 'If There Is No Struggle, There Is No Progress', a 'West India Emancipation' speech delivered at Canandaigua, New York, 03 August 1857, http://www.blackpast.org/1857-frederick-douglass-if-there-is-no-struggle-thereis-no-progress.

26.Perhaps Cornel West put it best in his description of 'the radical King': 'The radical King was first and foremost a revolutionary Christian ... whose intellectual genius and rhetorical power was deployed in the name of the Gospel of Jesus Christ. King understood this good news to be primarily radical love in freedom and radical freedom in love, a fallible enactment of the Beloved Community or finite embodiment of the Kingdom of God' (West 2015: Introduction, xv).

27.That South Africans have in fact not realised justice for the living in our reconciliation process to make that 'shared future' possible, durable and sustainable remains the challenge for this generation (see Allan Aubrey Boesak \& Curtiss Paul DeYoung 2012; see also Boesak 2017, especially chapters 4, 5, 6). 
his generation thought they should make in their time, to return to those methods in the 1970s and 1980s and build a movement of non-violent resistance that would ultimately break apartheid's back (see Boesak 2009).

Never losing sight of the agonising circumstances that forced our elders to make that decision, we nonetheless could define and defend our own stance: violence destroys the chances of peace and reconciliation in the irreversible destruction of the other. It casts the other in the mould of an unchangeable, incontrovertible enemy. It systematises as well as depersonalises the enemy. After the violent blow is struck, there are no more options left and the last word is already drowned in blood. Violence takes on a life of its own, feeds on human emotions far stronger than we realise, releases a relentless, deadly dynamic we are first not prone, then not able, to stop. It sweeps treason and better judgement aside as in ritualistic helplessness not acknowledgeable to ourselves we respond to the call of blood to blood. Lifting the sword destroys the soul. Non-violence appeals to our better selves, to the truth we know about ourselves as well as the other, but too often deny: that in our creaturely, relational existence and our common humanity we are created to affirm, choose and celebrate life rather than death. Non-violence affirms the humble acknowledgement of the possibility that we might be wrong, that the other is not just pure evil. It opens the way for the choosing of another path, to the ubuntufication of the other, because it longs for the affirmation of our humanity in the humanity of the other. Violence, in its irreversibility, is a reach too far for mortals such as us. Non-violence acknowledges the existence of holy ground: such as taking the life of another. We dare not tread upon it. ${ }^{28}$

\section{Radicalisation and domestication}

Across the world, whenever the name Martin Luther King Jr is mentioned, it is inevitably in conjunction with his famous Washington, DC, march 'I Have a Dream' speech. ${ }^{29}$ But let me confess: the Martin Luther King Jr whom the generation of young struggle activists embraced is the Martin of 1966, 1967 and 1968 rather than the Martin of 1963. The global citizen who recognised the global challenges of racism, poverty and war rather than the King who remained enchanted by the American dream. That King had become America's favoured son, stripped of his radicality, domesticated in dozens of presidential speeches - from Ronald Reagan to George W. Bush to Barack Obama - about his life on his birthday, his dream so hopelessly American that it is being claimed by the

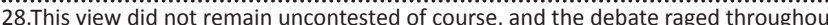
the 1980s, but remain uncontested of course, and the debate raged throughout those final phases of the struggle and held its ground as the bedrock of their belie and their participation the struggle. Honest appraisals of the situation in the 1980s will confirm that the violence in the streets was almost always provoked violence, within the broader framework of counter-violence to the inherent violence of apartheid. But this view on violence and non-violence remains my own firm conviction, even more so in a world drenched in blood through perpetual, needless, global war.

29.Martin King in full flight is on the cover of a book titled, Speeches that Changed the World, reprinted twice, among 49 great historical figures beginning with Jesus of Nazareth (the Sermon on the Mount). Abraham Lincoln has only one, King has two, the 'I Have a Dream' speech, and his last address on the eve of his assassination in Memphis on 03 April 1968, 'I Have Seen the Promised Land'. far right without a blush. ${ }^{30}$ Our embrace was of the King who, by 1966, had discovered that it was not at all about a seat at a lunch counter, but all about systemic justice; not so much about integration as about dignity and equality, and even then with the question attached: What kind of equality in what kind of society? Hence, his emphasis not so much on integration any more, but on the creation of a beloved community whose yardstick was justice to the poor and most vulnerable.

But as a result, the Martin we embraced saw the triple evils of racism, militarism and capitalist exploitation. That Martin embraced the political and economic potential of democratic socialism. That was the Martin who saw perpetual impoverishment as a critique of capitalism rather than as a mere by-product of racism; the Martin who mused that America should find a different economic system. 'There must be a better distribution of wealth and maybe America must move toward a democratic socialism' (Dyson 2000:88). ${ }^{31}$

We were captivated by the Martin King who observed and understood the revolutions that engulfed the world in his times, not because the people involved were simply prone to violence, but because they were, he said, 'revolting against old systems of exploitation and oppression', the Martin King who could now see, and identify with the 'shirtless and barefoot people of the land [who] are rising up as never before' (King 1967a:33). This is a radicalised Martin whose choice of words echo both Franz Fanon's 'wretched of the earth' and the Hebrew Bible's am ha'aretz, the people of the land, the poor and powerless peasants of Judea and Galilee who had so often revolted against their Roman imperial overlords.

That Martin who, in reference to the war in Vietnam, saw even then what would be and would remain, even more so today, 'the deepest malady within the American spirit': that war is poisonous to the soul of a nation, and that '[America] can never be saved as long as it destroys the deepest hopes of men [and women and children] the world over' (King 2015c:204). ${ }^{32}$

But I am afraid that means that the Martin that we embraced is the Martin Luther King America has so devoutly and

30.Probably the worst examples of the domestication and abuse of Martin Luther King can be seen in the way Americans from the far right have been shamelessly using him to defend their racist stances (e.g. right-wing Foxnews TV personality Glenn Beck), their resistance against affirmative action, a dignified minimum wage, and (ander justice issues. Even worse is the abuse of Martin King in defence of America's war policies. Baldwin and Burrows use the publications of Clarence B Jones, a one-time King advisor turned rabid conservative Republican who argues that Martin King would have supported George W. Bush in his invasion of Iraq and Afghanistan and his war policies in The Middle East (see Baldwin \& Burrows 2013:29-54; Jones 2011; Jones \& Engel 2008). 'Indeed', writes Michael Eric Dyson, 'conservatives must be applauded for their perverse ingenuity in coopting King's legacy and the rhetoric of the civil rights movement' (Dyson 2000:12).

31.Dyson explains how King was much more explicit on the subject of his leanings towards democratic socialism in private than in public, and he found this statement 'remarkable'. However, in an early comparative study on the ethics of Martin Luther King Jr, and Malcolm X I have probed the development of King's thinking on this matter and already then came to the conclusion that King was a 'latent socialist' (see Boesak 1974:39, 41).

32.See journalist Glenn Greenwald's reflections on the relevance of King's Riverside Church speech on Vietnam, and the lessons he draws for the United States and the world today, Glenn Greenwald, The Guardian, 22 January 2013. 
effectively domesticated and so determinedly watered down; the Martin America wants so feverishly to forget (Dyson 2000; Burrows \& Baldwin 2015; West 2015). For far too many in the rest of the world as well it is the Martin least remembered, least celebrated, least honoured. It is disturbing to see how much effort is going into creating a Martin Luther King more manageable, a prophet more palatable, a leader more pliable, a preacher more controllable.

But one, crucially important reason why, despite its undeniable beauty and soaring rhetorical heights, black South Africans of my generation were (and are) less drawn to the 'I have a dream' speech is not just because it has been so abominably abused over the last 50 years, almost made devoid of meaning. It is also because for us, people of the global South, the American dream is such a threatening, frightening thing. Malcolm X had persistently referred to the 'American Dream' as the 'American Nightmare' for African Americans (Malcolm X, ed. Breitman 1965:26) ${ }^{33}$ and by 1967 Martin King would concur. Referring to his speech at the Lincoln Memorial in 1963, he confessed, 'I talked to the nation about a dream that I had had, and I must confess to you today that not long after talking about that dream I started seeing that dream turn into a nightmare' (King 1968:75-76). Malcolm X was clear on this matter from the very beginning, but for perhaps too long Martin King held on to the myth that freedom for black people is ultimately secured because of America's inherent commitment to freedom. In consequence, and in light of the disappointment Barack Obama turned out to be, and the shameless racist bigotry and fascist tendencies of Donald Trump, it is not unfair to ask of African American brothers and sisters: Is at the core of the dilemma you face not perhaps the idea you have embraced from Martin's days up to now, that your freedom is, as Martin put it, 'the goal of America', and that your destiny is 'tied up in the destiny of America'? (King 2015b:142), and 'We will win our freedom because the sacred heritage of our nation and the eternal will of God are embodied in our echoing demands' (King 1986:277; King 2015b:143). ${ }^{34}$

What if, we might ask, with humility and some trepidation, but nonetheless with love and as honestly as we can, the destiny of America is indistinguishable from America's 'manifest destiny', which is based upon invasion, exclusion, expansionism, exploitation, genocide and imperial domination the world over?

\footnotetext{
33.In one of his last speeches given at Cory Methodist Church in Cleveland Ohio, 03 April 1964, Malcolm remained uncompromising on this matter: 'No, I am not an American. I am one of the 22 million black people who are the victims of Americanism. One of the 22 million black people who are the victims of democracy, nothing but a disguised hypocrisy. So I am not standing here speaking to you as an American, a patriot, or a flag-saluter, or a flag-waver-no, not I. I'm speaking as a victim of this American system. And I see America through the eyes of the victim. I don't see any American dream, I see an American nightmare'. But not even Malcolm had completely understood or could spell out the consequences of American exceptionalism for people of the Global South.

34.Martin King wrote this in his 'Letter from a Birmingham Jail' in 1963, but he has consistently clung to this language till the end; see, for example, in the sermon under discussion (King 2015b:277). It is a curious mixture of Christian nationalism, patriotism and American exceptionalism, perhaps an unsolved contradiction of which Martin was not unaware, that needs a more in-depth discussion than can be which Martin was not una
done in this contribution.
}

What if the American dream can only be upheld and realised by perpetual war not in service of freedom or democracy but in service to greed and the pursuit of profits?

What if the pursuit of the American dream has become the unbearable nightmare of those of us in the rest of the world where the name America does not conjure up 'sweet dreams of liberty' but night sweats drenched in terror, displacement and pain, and filled with images of such things as 'extraordinary rendition' and torture, perpetual war and endless occupation, cluster bombs, drones computerised death and the very real threat of nuclear destruction?

What if we admit that Barack Obama's famous chant, 'Yes, we can!' has migrated from an inspiring, hope-giving slogan to a fearsome expression of brute power: 'We exploit, attack, wage war, main and kill, "because we can!?"' as President Obama, shaking our dreams of renewed hopeful politics to the core, has so consistently, and devastatingly, shown throughout his term in office? (see Boesak 2015:90-122).

What if the American dream is no longer, perhaps never has been, the dream of a hopeful, compassionate people driven by the love for justice but the agenda of a heartless empire held captive by an outrageous, dehumanising, God-defying ambition for world domination? What if the American dream is not really a glittering vision 'from sea to shining sea' but the darkness of systemic executions from coast to coast of people of mixed race by militarised police, who, from Sanford, FL, to Ferguson, MO, to Standing Rock, ND, are, for this South African, a disorienting and frightening mirror image of the South African apartheid security forces? What if the shining 'city on a hill' has become inner cities of poverty, oppression and dispossession; of black neighbourhoods under siege, and white suburbs imprisoned by ignorance? What if the words of the American dream are no longer 'America the beautiful' but the lyrics of a nightmare: 'Don't shoot, I don't have a gun'; or 'please, don't let me die'; or 'I can't breathe'?

If Martin Luther King Jr were alive today, standing not in Selma, AL, but in Ferguson, MO; not in Birmingham, AL, but in New York City and Staten Island; not in Montgomery, AL, but in Standing Rock, ND; not in Chicago but povertystricken Thembisa and Khayelitsha; not in Selma, AL, but in gang-infested Bonteheuwel or Bishop Lavis, Cape Town, and the sprawling miasma of misery that we call 'squatter camps' or, more euphemistically, 'informal settlements?' What would those compassionate eyes see; what would that heart filled with revolutionary love for Christ and the world yearn for; what would that mind set on freedom think; what would that prophetic tongue say; what would those feet, restless for justice, do?

The lessons from the life, commitment, courage and power are far from fully learnt. Much remains. The Martin we 
learned to love and embraced is the Marin who taught us to stand up for justice and make those vital choices, his voice soaring in the National Cathedral:

On some positions, cowardice asks the question, is it expedient? And then expedience comes along and asks the question, is politic? Vanity comes along and asks the question, is it popular? Conscience asks the question, is it right? (King 1986:277)

King (1986) concludes:

There comes a time when one must take the position that is neither safe, nor politic nor popular; but [we] must do it because conscience tells $[u s]$ that it is right. (p. 277)

These are the penetrating questions that South Africans, in our restless and as yet unfulfilled search for an open, nonracial, non-sexist, people-centred, humane democracy, cannot avoid. As, in this time of resurging racism, tribalism and ethnocentrism, of all-consuming self-interest and selfdestructive entitlement, we cannot avoid the question of loyalties. 'Our loyalties must extend our race', Martin King said, because he understood the necessity of genuine nonracialism. 'We deem ourselves bound by allegiances and loyalties which are broader and deeper than nationalism' because he understood the essential oneness of our world and the call towards a common humanity. As a consequence, even if it meant speaking out against the leaders and politics of his own nation, he had to speak out 'for the weak, for the voiceless, for the victims of our nation, and for those it calls enemy, for no document from human hands can make these humans any less our brothers [and sisters]' (King 2015c:206). It is as if King had read and understood John Calvin clearly who insisted that:

the name 'neighbour' extends indiscriminately to every person, because the whole human race is united by a sacred bond of fellowship ... To make any person my neighbor it is enough that they be human. (Calvin, Opera, 45, 613, [italics added])

South Africa's Beyers Naudé understood King, as he understood the crucial nature of the distinction between what he called 'loyalties and lesser loyalties', the courage it would take to make that decision, and the courage it would take to sustain it:

In the Afrikaner society there is such a deep sense of loyalty ... Loyalty to your people, loyalty to your country, loyalty and patriotism have in a certain sense become deeply religious values ... So that anybody who is seen to be disloyal to his nation, to his people, is not only deemed to be a traitor, but in the deeper sense of the word, he is seen as betraying God. (Naudé \& Sölle 1986:11)

I have written extensively about the choices Beyers Naudé had decided to make, but it is worthwhile repeating the gist of it here (Boesak 2015:85-90). It is because he understood the totalitarian nature of that loyalty and its demands that he understood so well its consequences, and the choices it presented. A choice for those loyalties would be in direct opposition to the choices for Christ he had made. For that very reason he was always so clear on the demand for Christian obedience and loyalty to Christ above all, and the extent to which loyalty to Christ alone would make one understand the place of 'lesser loyalties', and how these lesser loyalties not just competed with one's loyalty to Christ, but in fact displaced it. It was especially dangerous because the 'lesser loyalties' claimed to be of God, and resisting them was presented as tantamount to resisting God. Then 'lesser loyalties' actually become 'false loyalties'. It is this combination of courage and conscience, of insight and foresight that enabled Beyers Naudé to see earlier and more clearly than others the deep and complex roots of the heresy of apartheid. It was not just the formal theological and biblical justification. It was as well, and dangerously so, the informal, insidious and all-pervasive cultural embodiment of a false, deceitful, carefully inculcated consciousness that presented itself as loyalty, and as Christian.

South Africans are once more faced with the vexing question of loyalty - to race or ethnic grouping, to tribe and class, to historical truth or self-serving myths; to gender justice and equality or patriarchal privilege and power; to the interests of the country or to the interests of the Party, the rightful demands of the people or the benefits of patronage. Beyers Naudé had learnt from both Dietrich Bonhoeffer and Martin Luther King, as he had learnt from Steve Biko. ${ }^{35}$ It is once again time to make those choices. We are indeed caught up in this 'inescapable network of mutuality', in this 'single garment of destiny'.

The Martin we embrace is the Martin who taught us the power of love as the most potent force in human relationships as well as in politics:

Darkness cannot drive out darkness, only light can do that. Hate cannot drive out hate; only love can do that. Hate multiplies hate, violence multiplies violence, and toughness multiplies toughness in a descending spiral of destruction. The chain of evil ... must be broken, or we shall be plunged into the dark abyss of annihilation. (King 1963a:53)

The Martin we love and embraced is the Martin who taught the world that hope is indispensable:

God grant that we will be participants in the newness (that God is creating) ... If we will but do it, we will bring about a new day of brotherhood [and sisterhood] and peace. And that day the morning stars will sing together and the children of God will shout for joy. (King, in Washington 278)

We embraced Martin Luther King Jr because he embraced our own Albert Luthuli, one of the most inspiring examples of Christian commitment to the struggles for freedom and justice the world over, and who today, above the desperate denials at the sickbed of our rainbow nation dreams, still

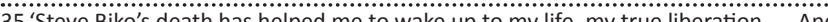
again, Steve Biko challenges me to not keep quiet anymore but to voice my deepest convictions about what is right and true, to stand up for them and to suffer for convictions about what is right and true, to stand up for them and to suffer for
them if necessary - even if this should mean that I have to endure condemnation and rejection by my own people' (Naudé, in Hansen, [ed.] 2005:79). 
speaks to his people, urging us to discard the destructive politics of illusion, and instead invest ourselves in the uplifting politics of hope and commitment:

The task is not yet finished. South Africa is not yet a home for all her sons and daughters. Such a home we wish to ensure. From the beginning our history has been one of ascending unities, the breaking of tribal, racial, and creedal barriers. The past cannot hope to have a life sustained by itself, wrenched from the whole. There remains before us the building of a new land, a home for [people] who are black, white, brown, from the ruins of the old narrow groups, a synthesis of the rich cultural strains which we have inherited ... Somewhere ahead there beckons a civilisation, a culture, which will take its place in the parade of God's history beside other great human syntheses, Chinese, Egyptian, Jewish, European. It will not be necessarily all black, but it will be African. (Luthuli [1960] 2006:230)

Such is the power of the networks of mutuality. These are the witnesses to prophetic truth, prophetic faithfulness and prophetic courage recognisable in all movements across the world dedicated to the subversion of systems of injustice, domination and subjugation; to freedom and the militant, non-violent transformation of societies; to the protection of life upon the Earth. Such lessons we have scarcely begun to understand, it seems to me, but they are nonetheless indispensable for a life of dignity, peacability and human flourishing, and for a democracy that is inclusive, humane, durable and sustainable.

\section{Acknowledgement Competing interest}

The author declares that no competing interest exists.

\section{Author contributions}

I declare that I am the sole author of this research article.

\section{Ethical consideration}

This article followed all ethical standards for carrying out research without direct contact with human or animal subjects.

\section{Funding}

This research received no specific grant from any funding agency in the public, commercial, or not-for-profit sectors.

\section{Data availability statement}

Data sharing is not applicable to this article as no new data were created or analysed in this study.

\section{Disclaimer}

The views and opinions expressed in this article are those of the authors and do not necessarily reflect the official policy or position of any affiliated agency of the authors.

\section{References}

Baldwin, L.V., 1995, Toward the beloved community, Martin Luther King Jr., and South Africa, Pilgrim, Cleveland, $\mathrm{OH}$.

Baldwin, L.V. \& Burrows, R., 2013, The domestication of Martin Luther King Jr., Clarence B. Jones, Right-Wing conservatism, and the manipulation of the King legacy, Wipf and Stock, Eugene, OR.

Baldwin, L.V., 2006, 'Martin Luther King Jr., a "Coalition of Conscience," and Freedom in South Africa', in R.D. Smith (ed.), Freedom's distant shores, American Protestants, and Post-Colonial alliances with Africa, pp. 53-82, Baylor University Press, Waco, TX.

Boesak, A.A., 1974, Coming in out of the wilderness, a comparative study of the ethics of Martin Luther King Jr., and Malcolm X, Kok, Kampen.

Boesak, A.A., 2009, Running with horses - Reflections of an accidental politician, JoHo!, Cape Town.

Boesak, A.A. \& DeYoung, C.P., 2012, Radical Reconciliation: Beyond Political Pietism and Christian Quietism, Orbis, Maryknoll, NY.

Boesak, A.A., 2014, Dare we speak of hope? Searching for a language of hope in faith and politics, Eerdmans, Grand Rapids, MI.

Boesak, A.A., 2015, Kairos, crisis, and global apartheid: The challenge to prophetic resistance, Palgrave Macmillan, New York.

Boesak, A.A., 2017, Pharaohs on both sides of the blood-red waters, prophetic critique on empire: Resistance, justice, and the power of the hopeful Sizwe, Cascade, Eugene, OR

Bond, P., 2004, 'Is the Reform really working?', The South Atlantic Quarterly 103(4), 817-839.

Botha, D.P., 1980, 'Church and Kingdom', in M. Nash (ed.), Thy Kingdom come, SACC, Braamfontein.

Breitman, G. (ed.), 1967, The last year of Malcolm X, The evolution of a revolutionary, Pathfinder, New York.

Burrows, R. \& Baldwin, L.V., 2015, The domestication of Martin Luther King Jr., Clarence B. Jones, Right-Wing conservatism, and the manipulation of the King Legacy, Wipf and Stock, Eugene, OR.

Calvin, J., 1985, Opera, 45, Challenge to the church - A theological comment on the political crisis in South Africa, The South African Kairos Document, South Africa pistory Online, viewed 23 October 2018, from http://www.sahistory.org.za/ History Online, viewed 23 October 2018 , from http://www.sahistory.org.za/ archive/challenge-church
kairos-document-1985.

Cone, J.H., 1991, Martin \& Malcolm \& America, a dream or a nightmare? Orbis, Maryknoll, NY.

Couper, S., 2010, Albert Luthuli, bound by faith, University of KwaZulu-Natal Press, Pietermaritzburg.

Douglass, F., 1857, 'If there is no struggle, there is no progress', A West India Emancipation, Speech, viewed23 October 2018, from https://www.blackpast. org/1857-frederick-douglass-if-there-is-no-struggle-t.here-is-no-progress.

Dyson, M.E., 2000, I may not get there with you - The true Martin Luther King Jr., Touchstone, New York.

Hansen, L. (ed.), 2005, The legacy of Beyers Naudé, Sun Media, Stellenbosch.

Jones, C.B., 2011, Behind the dream - The making of the speech that transformed a nation, St. Martin's, New York.

Jones, C.B. \& Engel, J., 2008, What would Martin Say? Harper Collins, New York.

King, M.L. Jr, 1963a, Strength to love, Harper and Row, New York.

King, M.L. Jr, 1963b, Why we can't wait, Harper and Row, New York.

King, M.L. Jr, 1967a, The trumpet of conscience, Harper and Row, New York.

King, M.L. Jr, 1967b, Where do we go from here? Chaos or community? Harper and Row, New York.

King, M.L. Jr, 1986, 'Remaining awake through a great revolution', in J.M. Washington (ed.), A testament of hope, the essential writings of Martin Luther King Jr. pp. 268-278, Harper and Row, San Francisco, CA.

King, M.L. Jr, 2015a, 'Let my people go', in T.C. West (ed.), The radical king, pp. 107-112, Beacon, Boston, MA.

King, M.L. Jr, 2015b, 'Letter from a Birmingham Jail', in T.C. West (ed.), The radical king, pp. 127-146, Beacon, Boston, MA.

King, M.L. Jr, 2015c, 'Where do we go from here?', in T.C. West (ed.), The radical king, pp. 178-189, Beacon, Boston, MA.

King, M.L. Jr, 2015d, 'Beyond Vietnam', in T.C. West (ed.), The radical king, pp. 201-217, Beacon, Boston, MA.

Kinghorn, J. (ed.), 1986, Die N.G. Kerken Apartheid, Macmillan, Johannesburg.

Lombard, R.T.J., 1981, Die Nederduitse Gereformeerde Kerke en Rassepolitiek, D.R. Church Publishers, Silverton.

Luthuli, A., [1960] 2006, Let my people go! The autobiography of Albert Luthuli, Tafelberg/Mafube, Cape Town.

Naudé, C.F.B., 1963, My decision, The Christian Institute, Johannesburg.

Naudé, B. \& Sölle, D., 1985, Hope for faith, a conversation, Eerdmans, Grand Rapids, MI.

Smith, R.D. (ed.), 2006, Freedom's distant shores, American Protestants and PostColonial alliances with Africa, Baylor University Press, Waco, TX. 
The Belhar Confession, viewed 23 October 2018, from https://www.pcusa.org/site/ media/media/uploads/theologyandworship/pdfs/belhar/pdf.

Van der Westhuyzen, M.J., 1948, Redakteursbrief (Editorial), Die Kerkbode, 22 September 1948, pp. 664-665.

Washington, J.M. (ed.), 1986, A Testament of hope: The essential writings of Martin Luther King Jr, Harper and Row, San Francisco, CA.
West, T.C. (ed.), 2015, 'The radical King we don't know' (Introduction), in T.C. West (ed.), 2015, The Radical King, pp. ix-xvi, Beacon, Boston, MA

West, T.C. (ed.), 2015, The Radical King, Beacon, Boston, MA.

West, T.C., 2015, 'Gay rights and the misuse of Martin', in L.V. Baldwin, \& R. Burrows (eds.), The domestication of Martin Luther King Jr., Clarence B. Jones, Right-Wing conservatism, and the manipulation of the King legacy, pp. 141-156, Wipf and Stock, Eugene, OR. 